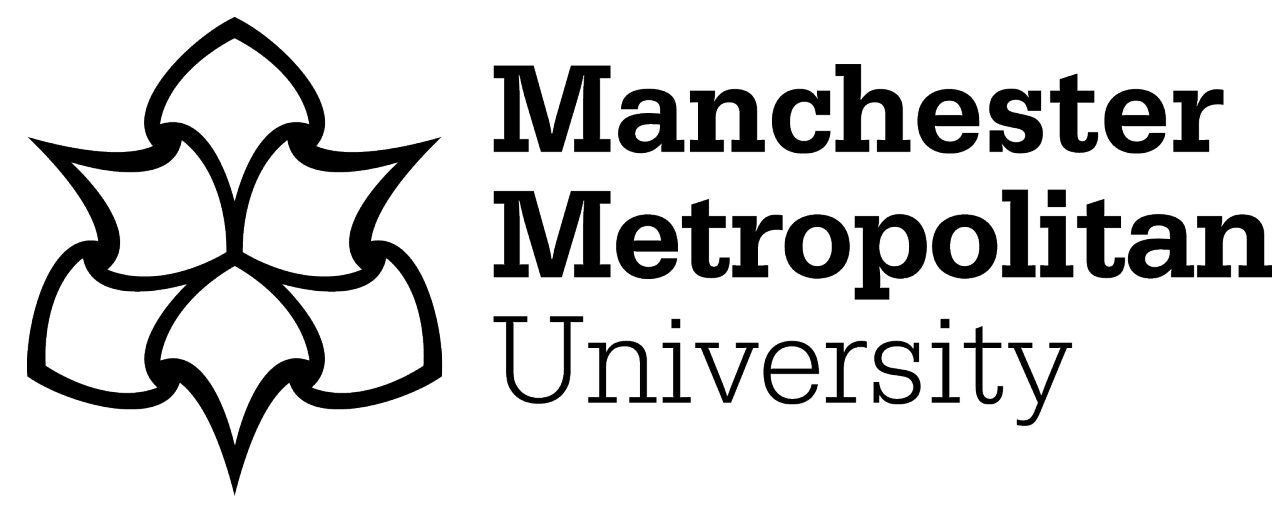

Roche, JT (2021) "Crusaders" and the Islamic State Apocalypse. International Journal of Military History and Historiography, 41 (2). pp. 308-342. ISSN 2468-3299

Downloaded from: https://e-space.mmu.ac.uk/629026/

Version: Accepted Version

Publisher: Brill

DOI: https://doi.org/10.1163/24683302-bja10017

Please cite the published version 


\title{
"Crusaders" and the Islamic State Apocalypse
}

\author{
Jason T. Roche \\ Department of History, Politics and Philosophy, Manchester \\ Metropolitan University, Manchester, UK \\ j.t.roche@mmu.ac.uk
}

\begin{abstract}
Islamic State propaganda manipulated and combined a culturally embedded sense of Islamic history with a heady, potent mixture of classical and radical apocalyptic, and real and supposed Islamic authority, both sacred and profane. Tapping into a widespread belief in the approach of the Last Hour, the group attempted to change an established "crusader master narrative" by giving "crusaders" and their "crusade" integral roles in Islamic sacred history and an impending Islamic State apocalypse.
\end{abstract}

According to Jeffrey Halverson, "master narratives" employed by Islamist groups are compelling for many people because "they possess an internal coherence for the audiences that connects them to grand, deeply culturally embedded, views of history - to master narratives that Muslim audiences, in broad terms, readily understand, identify with, or feel little need to

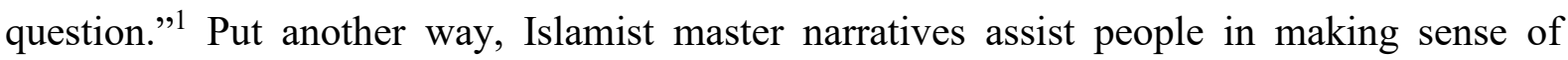
present, often perceived as oppressive circumstances, by connecting those circumstances to an existing awareness of Islamic history. ${ }^{2}$ As Halverson points out, that history, that narrative, supposedly includes a watershed moment: the invasion of Muslim lands by the First Crusaders at the end of the eleventh century and the violence and destruction that attended the Latin settlers' occupation of Palestine and parts of Syria. ${ }^{3}$ The occupation nearly ended with the

\footnotetext{
${ }^{1}$ Jeffrey Halverson, H. Lloyd Goodall, and Steven Corman, Master Narratives of Islamist Extremism (New York, 2011), 13. See also Nathan C. Funk, and Abdul Aziz Said, "Islam and the West: Narratives of Conflict and Conflict Transformation", International Journal of Peace Studies 9 (2004): 1-28. Islamism is defined as "a political ideology that bases its legitimacy on narratives and interpretations derived from the religion of Islam, specifically the Quran and prophetic traditions (hadith) as well as early, classical and modern Muslim history, customs and tradition". The "goal of Islamism is the reorganisation of Muslim states and societies according to the norms, values, systems and institutions advocated by its proponents, which they declare to be 'Islamic' or part of the religion of Islam". See Samantha Mahood and Halim Rane, "Islamist Narratives in ISIS Recruitment Propaganda", The Journal of International Communication 23 (2017): 15-35 (quotations at 15).

2 J. M. Berger has demonstrated how violent Islamist narratives tend to bundle elements of folklore and mythology with religious scriptures and historical events to present a self-reinforcing historical "proof". These bundles can be linked with other narrative typologies to construct highly complex, interconnected concepts that support an overarching narrative. See J. M. Berger, "Extremist Construction of Identity: How Escalating Demands for Legitimacy Shape and Define In-Group and Out-Group Dynamics", The International Centre for CounterTerrorism - The Hague 8 (2017): DOI:10.19165/2017.1.07. David Zeidan touched on a range of violent Islamist narrative typologies in his "The Islamic Fundamentalist View of Life as a Perennial Battle", Middle East Review of International Affairs 5 (2001): 26-53. Dina Al Raffie discusses links between mainstream Islamic narratives and violent Islamist narratives in her "Hearts and Minds? Narratives and Counter Narratives of Salafi Jihadism", Journal of Terrorism Research 3 (2012): 13-31.

${ }^{3}$ Muslim contemporaries rarely thought of the Latin occupation of Palestine and parts of Syria and Mesopotamia in the first decades of the twelfth century as watersheds in Muslim-Christian relations or Islamic history. During the twelfth and thirteenth centuries, the crusaders and the Latin settlers in the Levant were often considered just another group of military elites who had, or who had attempted to impose their will on the native Muslim, Christian
} 
emergence of the Muslim champions Nūr al-Dīn b. Zangī and Șalāḥ al-Dīn Yūsuf ibn Ayyūb who, with their victories against the invaders, initiated a reversal in Latin Christian fortunes during the second half of the twelfth century. ${ }^{4}$

Samantha Mahood and Halim Rane have recently examined the "crusader master narrative" in the copious propaganda output of the so-called Islamic State (IS) militant Islamist group and they suggest that the narrative is very powerful. ${ }^{5}$ They argue that the group invoked the crusades to provide legitimacy for its argument that the "Christian West" was, and always has been engaged in a struggle against Islam. ${ }^{6}$ In doing so, IS propaganda capitalised "upon the historical injustice of the Crusades in order to legitimise its social and political vision" by presenting the group's fighters as modern champions and defenders of the whole community of Muslims, the ummah, against forms of western intervention and perceived oppression. ${ }^{7}$ Mahood and Rane's examination sits in a growing corpus of work that seeks, amongst other things, insights into IS's ideologies, motivations and strategic objectives by identifying, mapping, characterising and contextualising the various messages and narrative typologies found in IS propaganda. ${ }^{8}$

The aims of this article are very different. There is no intention to explore the main drivers of IS mobilisation or the shifting geopolitical contexts of IS propaganda. Nor does the article

and Jewish populations. See Nikita Elisseeff, "The Reaction of the Syrian Muslims after the Foundation of the First Latin Kingdom of Jerusalem", in Crusaders and Muslims in Twelfth-Century Syria, ed. Maya Shatzmiller (New York, 1993), 162-72; Carole Hillenbrand, The Crusades: Islamic Perspectives (Edinburgh, 1999), 20; Joseph Drory, "Early Muslim Reflections on the Crusaders", Jerusalem Studies in Arabic and Islam 25 (2001): 92-101; Mona Hammad and Edward Peters, "Islam and the Crusades: a Nine Hundred-Year-Long Grievance?", in Seven Myths of the Crusades, ed. Alfred J. Andrea and Andrew Holt (Indianapolis, IN, 2015), 127-49 (here 133-35). Also see Paul Cobb, The Race for Paradise: An Islamic History of the Crusades (Oxford, 2014). Even the massacre at Fatimid (Ismaili Shi'ite) controlled Jerusalem in 1099 by the soldiers of the First Crusade barely registered in contemporary Islamic texts. See Konrad Hirschler, "The Jerusalem Conquest of 492/1099 in the Medieval Arabic Historiography of the Crusades: From Regional Plurality to Islamic Narrative", Crusades 13 (2014): 37-76.

${ }^{4}$ Halverson, Goodall and Corman, Master Narratives, 109-24.

${ }^{5}$ The literature on the so-called Islamic State is extensive. With particular reference to IS apocalyptic, full-length studies include William McCants, The ISIS Apocalypse: The History, Strategy, and Doomsday Vision of the Islamic State (New York, 2015); and Bronislav Ostřansky, The Jihadist Preachers of the End Times: ISIS Apocalyptic Propaganda (Edinburgh, 2019). The latter book was published too late to influence the present article and in no way challenges the article's arguments and conclusions.

${ }^{6}$ See also Halverson, Goodall and Corman, Master Narratives, 124.

${ }^{7}$ Mahood and Rane, "Islamist Narratives in ISIS Recruitment Propaganda", 24. See also Halim Rane, "Narratives and Counter-Narratives of Islamist Extremism", in Violent Extremism Online: New Perspectives on Terrorism and the Internet, eds. Anne Aly, Stuart Macdonald, Lee Jarvis, and Thomas Chen (London, 2016), 167-86 (here 173); see also Alastair Reed and Jennifer Dowling, "The Role of Historical Narratives in Extremist Propaganda", Defence Strategic Communications 4 (2018): 79-104 (here 85-86).

8 See, for example, Lawrence A. Kuznar, "The Stability of the Islamic State Narrative: Implications for the Future", Dynamics of Asymmetric Conflict 10 (2017): 40-53; Tyler Welch, "Theology, Heroism, Justice, and Fear: An Analysis of ISIS Propaganda Magazines Dabiq and Rumiyah", Dynamics of Asymmetric Conflict 11 (2018): 186-198; Haroro J. Ingram, “Islamic State's English-Language Magazines, 2014-2017: Trends \& Implications for CT-CVE Strategic Communications", The International Centre for Counter-Terrorism - the Hague 15 (2018): DOI:10.19165/2018.1.03; Reed and Dowling, "The Role of Historical Narratives in Extremist Propaganda", 79-104. IS was adept at combining or otherwise tailoring its core narratives to suit audiences in different parts of the world: Daveed Gartenstein-Ross, Nathaniel Barr, and Bridget Moreng, "The Islamic State's Global Propaganda Strategy", The International Centre for Counter-Terrorism - the Hague 7 (2016): DOI:10.19165/2016.1.01. 
propose to gauge the importance and impact of the "crusader master narrative" in the strategic thinking and objectives of IS's leadership. Instead, the article offers a novel exposition of a neglected mutation in the "crusader master narrative" as presented in IS's international flagship magazines, Dabiq and Rumiyah. The magazines constitute the group's most well-known and influential tools of propaganda for western audiences and provide a large, reasonably consistent and accessible corpus of evidence.

Scholars are correct to note the ubiquitous words "crusade" and "crusader" in IS propaganda and particularly in Dabiq and Rumiyah. ${ }^{9}$ But such scholars have not recognised that - except for two occasions, as noted below - Dabiq and Rumiyah do not refer to the Christian military campaigns to the Levant in the central Middle Ages that specialist historians would call crusades. Nor does that literature refer to the creation of the Latin states of Outremer by the first generation of crusaders and Latin settlers. Put another way, IS literature does not contain profuse references to the actual crusades or crusaders. The group's flagship magazines rely instead on the existing familiarity within the Islamicate with modern anachronistic and ahistorical popular retellings of an imperialist and anti-Islamic medieval crusading movement. ${ }^{10}$ These stories constitute the core key elements of the "crusader master narrative" as propagated in a range of literature and media spanning the works and proclamations of Islamist fundamentalists such Sayyid Qutb and Osama bin Laden through to children's textbooks, best sellers and television documentaries. ${ }^{11}$ The very terms "crusade" and "crusader" are emotive and resonate with the imperialist and anti-Islamic inferences and assumptions of the "crusader master narrative" within the Islamicate. The flagship magazines employed the terms "crusade" and "crusader" in this metonymic sense, and it was the expected

\footnotetext{
${ }^{9}$ See, for example, Halverson, Goodall and Corman, Master Narratives, 185; Mahood and Rane, "Islamist Narratives in ISIS Recruitment Propaganda", 23; Reed and Dowling, "The Role of Historical Narratives in Extremist Propaganda", 85; Akil N. Awan, "Weaponising the Crusades: Justifying Terrorism and Political Violence", in The Crusades in the Modern World (Abingdon, 2020), 4-24 (here 19); Stephane J. Baele, et al., "ISIS's Clash of Civilizations: Constructing the 'West' in Terrorist Propaganda", Studies in Conflict \& Terrorism (2019): DOI:10.1080/1057610X.2019.1599192.

${ }^{10}$ The popular notion that a memory of the crusades had passed from generation to generation in certain areas of the Islamicate is tenuous. As is becoming well known, there is very little empirical evidence to suggest that the Levantine crusades were "remembered" in the modern Islamicate before the mid-nineteenth century; see, for example, Umej Bhatia, Forgetting Osama bin Munqidh. Remembering Osama bin Laden: The Crusades in Modern Muslim Memory (Singapore, 2008), 19; Jonathan Riley-Smith, The Crusades, Christianity and Islam (New York, 2008), 67-71; Hammad and Peters, "Islam and the Crusades", 127-49; Awan, "Weaponising the Crusades", 6.

${ }^{11}$ Bhatia, Forgetting Osama bin Munqidh, 6-15, 39-47; Mazhar Al-Zo'by, "'Frankish Invasions' and 'a Cosmic Struggle Between Islam and Christianity' - a View from Jordan", in Controversial Histories - Current Views on the Crusades, eds. Felix Hinz and Johannes Meyer-Hamme (Abingdon, 2020), 24-25; Taef Kamal El-Azhari, "The Former Victors Over the Crusades in Palestine - a View from Egypt", in Controversial Histories, eds. Hinz and Meyer-Hamme, 45-46; Mehmet Ersan, "A Hostile and Aggressive Stance of the West Towards Turkey Based on Othering and a Double Standard - a View from Turkey", in Controversial Histories, eds. Hinz and MeyerHamme, 47-49; Mohamad Isa, "A State of Continuous Rape and Violation - a View from Syria", in Controversial Histories, eds. Hinz and Meyer-Hamme, 62-63. Note: there has never been a uniform "Muslim" view of the crusades, with modern approaches to the field of study ranging from scholarly balanced historicism to the significantly more popular anachronistic, ahistorical narratives.
} 
emotive response to the terms, rather than the actual storey of the rise and fall of the so-called Crusader States, that IS literature attempted to exploit. ${ }^{12}$

The scope, depth and connotations of the terms "crusade" and "crusaders" in IS propaganda are indeed more complex than has hitherto been recognised. As this article will establish, the group's literature built on the ideas of earlier militant Islamist fundamentalists and exploited a widespread belief in the approach of the cataclysmic conclusion of time as promulgated in radical messianic literature that likewise employed the terms "crusade" and "crusader" as metonyms. By so doing, IS propagandists attempted to imbue the "crusader master narrative" with new meanings. "Crusaders" became the demonic enemies of Islam identified in the "Portents of the Hour" and "Amāq Cycle" prophetic traditions (as appended to the article). Western intervention in the Near East - the supposed "crusade" against Islam - was nothing less than the literal work of the Antichrist and a harbinger of the apocalypse.

\section{The "Crusader Master Narrative" and Militant Islamist Fundamentalists}

Sayyid Qutb (1906-66), an Egyptian nationalist turned Islamist fundamentalist and leading member of the Muslim Brotherhood in the 1950s and 1960s is widely acknowledged as the chief ideologue of Salafi-jihadism and modern pan-Islamist militancy. ${ }^{13}$ His Milestones, first published in 1964, held out hope of a reversal of fortunes for the ummah in line with the narrative arc of the "crusader master narrative" as discussed by Halverson, and he added a significant nuance to the existing, Arab nationalists' constructs of the crusades. ${ }^{14}$ He wrote that "Christendom" was trying to deceive Muslims

by distorting history and saying that the Crusades were a form of imperialism. The truth of the matter is that the latter-day imperialism is but a mask for the crusading spirit, since it is not possible for it to appear in its true form, as it was possible in the Middle Ages. The unveiled crusading spirit was smashed against

\footnotetext{
12 The words "west", "western", "Rome" and "Roman" likewise have imprecise meanings in IS literature and are employed as metonyms. For "west" and "western", see Baele et al., "ISIS's Clash of Civilizations". On "Rome" and "Roman", see below.

${ }^{13}$ For introductions to Sayyid Qutb and his ideas, influence and influences see Gilles Kepel, Jihad: The Trail of Political Islam, trans. Anthony F. Roberts (Cambridge, MA, 2002), 25-32; Bhatia, Forgetting Osama bin Munqidh, 22-24; Halverson, Goodall, and Corman, Master Narratives, 114-16; Mehdi Laghmari, "Situating Islamic State's Message: A Social and Theological Genealogy”, in ISIS Propaganda: A Full-Spectrum Extremist Message, eds. Stephane Baele, Katharine Boyd, and Travis Coan (Oxford, 2019), DOI:10.1093/oso/9780190932459.003.0003.

${ }^{14}$ Following the dismemberment of the Ottoman Empire at the end of the First World War and the creation of mandates out of former Ottoman possessions in Syria, Mesopotamia and Palestine, Arab nationalist thinkers digested European constructs of the crusades and began to present their struggle against the English and French mandates as a riposte to an imperialist "crusade" that was being waged against them. Zionism, the movement that secured national privileges and territory in Palestine for the Jews, inspired Jewish thinkers and their Arab opponents to regard it as a form of western colonialism, analogous to what those thinkers understood to be the colonial nature of the Latin states of Outremer in the central Middle Ages. Henceforth, Zionism became identified with (imperial) "crusaderism”. See Riley-Smith, The Crusades, Christianity and Islam, 53-61, 71-73; Bhatia, Forgetting Osama bin Munqidh. 22; Hammad and Peters, "Islam and the Crusades", 135-38, 144-46.
} 
the rock of the faith of Muslim leadership which came from various elements, including Salahuddin the Kurd. ${ }^{15}$

Western historiography, which had informed the Arab nationalists' ideas on the crusades in the wake of the First World War, still largely framed the campaigns as imperial endeavours in 1964. But according to Sayyid Qutb, the historiography was "distorting history": the western "imperialism" in the Levant in the central Middle Ages and the western presence and influence in the region in his day not only amounted to the same western endeavour, it also constituted a unique type of imperialism. He argued that an insatiable and irrational hatred of Islam and a thirst for its destruction, something he defined as a "crusading spirit", was the motor driving the historical Levantine crusades. The "crusading spirit" was supposedly inherent, inherited and lay latent in the minds of everyone of European descent and was the driving force behind British colonialism in Egypt and Zionism in Palestine. According to Sayyid Qutb, the crusades were and continued to be - no less than ideological and cultural attacks on Muslims and Islam. ${ }^{16}$

Key elements of Sayyid Qutb's ideas and writings, which were collected, edited and published by his brother, Muhammad Qutb in Saudi Arabia, were popularised by Muhammad's famous student and once the darling of militant Islamists the world over, Osama bin Laden, the Saudi leader of the al-Qā ' ida radical Islamist group. ${ }^{17}$ From the fatawā issued in August 1996 and February 1998 against the "Crusaders" and "Zionist-Crusaders" then present in Saudi Arabia

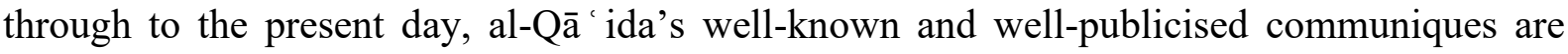
peppered with references to modern "crusaders". ${ }^{18}$ These so-called "crusaders" purportedly share with the historical crusaders of the central Middle Ages the alleged western hatred towards Islam that has supposedly existed since the eleventh century. Perpetuating the imagined link between the crusaders of the central Middle Ages and modern western forces seems to demonise the latter and their interventions in the Near East in religiously ideological ways. But more than the "crusaders" conceived by Sayyid Qutb, those fashioned by Osama bin Laden and his chief ideologue, Ayman al-Zawāhirī, were bent on material neo-colonial rather than religious/cultural-ideological endeavours in the Near East. ${ }^{19}$

The Dabiq and Rumiyah magazines are replete with allusions to the works and ideas of Sayyid Qutb and Osama bin Laden. For example, the foreword to Dabiq 7 cites and echoes, sometimes verbatim, the words of Osama bin Laden expressed during an interview with the al-Jazeera correspondent Tayseer Allouni in October 2001. ${ }^{20}$ Here the so-called war on terror was "yet

\footnotetext{
${ }^{15}$ Sayyid Qutb, Milestones, trans. unknown, ed. A. B. al-Mehri (Birmingham, 2006), 177.

${ }^{16}$ See also Sayyid Qutb, "Social Justice in Islam", in Sayyid Qutb and Islamic Activism: A Translation and Critical Analysis of 'Social Justice in Islam', ed. William E. Shepard (Leiden, 1996), 309-311; Bhatia, Forgetting Osama bin Munqidh, 22-24; Halverson, Goodall, and Corman, Master Narratives, 114-16.

${ }^{17}$ Kepel, Jihad, 51.

${ }^{18}$ Osama bin Laden, "Declaration of War against the Americans Occupying the Land of the Two Holy Places", accessed 28 February, 2020, https://is.muni.cz/el/1423/jaro2010/MVZ203/OBL__AQ_Fatwa_1996.pdf. Osama bin Laden, "Jihad Against Jews and Crusaders", accessed 28 February, 2020, https://fas.org/irp/world/para/docs/980223-fatwa.htm.

${ }^{19}$ Zeidan, "The Islamic Fundamentalist View of Life", 35-36, 44-47.

${ }^{20}$ Osama bin Laden, Unreleased interview by Tayseer Allouni, October 21, 2001, accessed 28 February, 2020, https://www.terrorisme.net/2002/08/19/obl-interview/.
} 
another crusade like the former crusades led by Richard the Lionheart, Barbarossa of Germany and Louis of France. Likewise today, when Bush raised the cross, the crusader countries immediately scrambled." ${ }^{21}$ This is one of only two references in the flagship magazines to actual crusades or crusaders. ${ }^{22}$ King Richard I "the Lionheart" of England led an army during the Third Crusade (1188-92), as did Emperor Frederick I "Barbarossa" of Germany (who was also a veteran of the Second Crusade to the Levant in 1147-48). Louis of France almost certainly refers to King Louis IX of France who went on crusade in 1248-54 and $1270 .{ }^{23}$ Osama bin Laden's reference to George W. Bush raising "the cross" is an obvious allusion to the US president's infamous "this crusade, this war on terrorism, is gonna [sic] take a while" quip at the Rose Garden press conference in the wake of the terrorist attacks on 11 September $2001 .^{24}$ The al-Q'a ' ida leader seized upon Bush's ill-judged and unscripted comment in response to the 9/11 attacks as proof that western intervention in the Near East constituted a crusade. He expressed outrage during the interview with Tayseer Allouni: “when Bush speaks, people make apologies for him and they say that he didn't mean that this war is a crusade, even though he said himself that it was a crusade." 25

Rumiyah 2 followed Osama bin Laden's reasoning while also invoking the ideas of Sayyid Qutb:

the old colonialism was but a front for the Crusaders, just as it is today a front for the Jews and Christians. Indeed, the "Caesar of Rome" Bush has declared multiple times that, "It is a Crusade!" So why do people lie and deny this? ${ }^{26}$

The magazine alludes to Sayyid Qutb's belief that the historical Levantine crusades - or the "old colonialism" as they are collectively called here - (echoing Mansur Abdelhakim's earlier use of the phrase "old colonial policy" as noted below) masked the alleged "crusading spirit". The allusion is followed by an explicit mention of Bush's reference to the "war on terrorism" as a "crusade" and Osama bin Laden's anger at the Bush administration's moves to disassociate the president from the ripe implications of the word. ${ }^{27}$

\footnotetext{
21 "Foreword", Dabiq 7, Rabi Al-Akhar 1436: 3.

22 "In the Words of the Enemy", Dabiq 15, Shawwal 1437: 74-75 notes Pope Urban II's sermon at the Council of Clermont in 1095 where he called for what is now known as the First Crusade (1095-99). The magazine proclaims that the sermon "launched the Crusades, which continue today".

${ }^{23}$ Christopher Tyerman, God's War: A New History of the Crusades (London, 2006), 329-38, 417-30, 431-74, 781-99, 811-12.

24 George W. Bush, Speech of September 16, 2001, accessed 28 February 2020, https://georgewbushwhitehouse.archives.gov/news/releases/2001/09/20010916-2.html.

${ }^{25}$ Osama bin Laden, Unreleased interview.

26 "Paths to Victory - Part 1", Rumiyah 2, Muharram 1438: 19.

${ }^{27}$ Andrew Fiala discusses Bush's sole public use of the word crusade and the so-called Bush Doctrine in several places: "The Crusade for Freedom: A Just War Critique of The Bush Doctrine", The Journal of Political Theology 9 (2008): 47-60; "The Bush Doctrine, Democratization, and Humanitarian Intervention: A Just War Critique", Theoria: A Journal of Social and Political Theory 114 (2007): 28-47; "Crusades, Just Wars, and The Bush Doctrine", Peace Review 19 (2007): 165-72.
} 
While the debt owed to Osama bin Laden's and al-Q'̄ 'ida's ideas on the crusades and crusaders are clear in the IS magazines, the group's conception of the supposed modern crusades and crusaders are closer to that of Sayyid Qutb's, and, as we shall see, that of Abu Mus 'ab al-Sūrī, the so-called "architect of global jihad". ${ }^{28}$ With a nod to the supposed innate reality of the "crusading spirit", Pope Francis was accused of hiding "behind a deceptive veil" with his messages of reconciliation between Christians and Muslims "covering his actual intentions of pacifying the Muslim nation." ${ }^{29}$ Elsewhere, IS declared, "the enmity of the kafir [nonbeliever]... is never based in an economic or political motive. It is only... a matter of religion." 30 The group's magazines reinforced the notion that its "crusader" adversaries were at war with IS for religious rather than material concerns by, for example, referring to their enemies as "the armies and legions of the cross" and the "worshippers of the cross". ${ }^{31}$ IS's "crusaders" were in fact a different breed of neo-colonialists. As will be demonstrated, the group's propaganda exploited the immense popularity of radical apocalyptic literature, which, as sketched below, identified Christian Zionism and the Antichrist with its "crusader" agents as the chief enemies of Sunni Islam. The "crusaders" now had cosmic roles in the Islamic State apocalypse. Bush's "crusade" became transcendental. ${ }^{32}$

\section{The "Crusader Master Narrative" and the Cosmic Turn}

Millennial ideas and agenda influenced the Iranian Revolution and the launch of the first Islamic (Sharia-based) society of the modern world (1979), the Iran-Iraq War (1980-88), the creation of Hamas (1987), the Mujahedeen's victory over the Soviet Union in Afghanistan (1989), and the birth of a second Sharia-based society in Taliban-controlled Afghanistan (1996). At the same time, and seemingly drawing encouragement from the upheavals in the Near East, the 1980s and particularly the 1990s spawned an incredibly popular flood of Cairo-based radical messianic literature. The books and pamphlets appear, in part, to have been formulated in response to, and certainly drew freely from various scriptural and contemporary fundamentalist Judeo-Christian apocalypses to break with the conventions of classical Islamic tradition. ${ }^{33}$ Nearing the end of the second millennium and more noticeably after the events of 9/11 and the intervention of Western nations in Afghanistan, this new apocalyptic landscape went mainstream and increasingly began to take on anti- "crusader" and anti- "Byzantine", or rather,

\footnotetext{
${ }^{28}$ Note: due almost certainly to certain ideological and theological reasons, IS propaganda never refers to Sayyid Qutb or acknowledges his influence; see Mehdi, "Situating IS' Propaganda".

29 "In the Words of the Enemy", Dabiq 15, Shawwal 1437: 75.

30 "Paths to Victory - Part 1", Rumiyah 2, Muharram 1438: 19.

31 "Important Advice for the Mujahidin: Part 2", Rumiyah 12, Dhul Qadah 1438: 30; "It Will Be a Fire that Burns the Cross and its People in Raqqah", Rumiyah 12, Dhul Qadah 1438: 35.

32 The is propagandists added a significant nuance here to Sayyid Qutb's belief that Jews had been engaged in a cosmic struggle with Muslims since the seventh century. See Ronald L. Nettler, Past Trials and Present Tribulations: A Muslim Fundamentalist's View of the Jews (Oxford, 1987).

${ }^{33}$ David Cook, Contemporary Muslim Apocalyptic Literature (New York, 2005), 18-58; Yvonne Y. Haddad and Jane I. Smith, "The Anti-Christ and the End of Time in Christian and Muslim Eschatological Literature", The Muslim World 100 (2010): 505-29; Jean-Pierre Filiu, Apocalypse in Islam, trans. M. B. DeBevoise (Berkeley and Los Angeles, CA, 2011), 70-74, 80-103. See also Zeidan, "The Islamic Fundamentalist View", 36-39; Richard Landes, "Enraged Millennialism: Global Jihad (1400-1500 ah /1979-2076 ce", in Heaven on Earth: The Varieties of the Millennial Experience (Oxford, 2011), 421-66 (here 421-24, 438-39, 445-60).
} 
anti-Christian Zionist and anti-Western/American overtones. Popular authors almost universally believed that they were living in the Last Days, although their apocalyptic scenarios were frequently at odds with classical Muslim apocalyptic literature, even while alluding to the classical traditions. Muhammad 'Isa Da'ud, a very popular Egyptian pamphleteer, drew on the authentic Amāq traditions appended to the article when he transformed the "Byzantines" - the implacable and satanic enemy of Islam identified in the hadith - into western forces that had engaged in conflicts such as the Kuwait war (1990-91) and the war in Bosnia and Herzegovina $(1992-95){ }^{34}$

Da'ud and others like him took a keen interest in the activities of North American Christian fundamentalists and counted George W. Bush amongst the Christian Zionists. "President Bush's announcement of a new Crusade in the East is anything but a slip," Da'ud advised his readers, for "the Americans frankly consider themselves God's representatives on earth, [and believe that] their actions therefore correspond to divine will." ${ }^{35}$ The dissident Saud Shaykh Safar al-Hawali, a man whose radicalism is credited with inspiring global jihadists and a generation of radical messianic authors, seems to have obsessed most over fundamentalist Christianity, then ascendant "in the White House and the Pentagon" under George W. Bush. ${ }^{36}$ In popular books and audiotapes, Safar al-Hawali had already discussed how "Western Crusaders" carried out their designs in the Gulf and Near East region. ${ }^{37}$ Importantly, he went on to identify Christian Zionism as the chief enemy of Islam and, building on the earlier assimilation of biblical material by radical messianic authors who seemingly wished to communicate their theories to a Christian audience, he set about turning Christian apocalypses back against the American partisans of Israel. In doing so, he developed an anti-American eschatology based in great part on the Christian-Zionist corpus in which Muslims - not Christian Zionists - would remain saved and triumphant at the End of Time. ${ }^{38}$

The Anglo-American invasion of Iraq in 2003 changed again the nature of such apocalyptic literature. A mass of popular writers now accepted Christian Zionism as the chief enemy of Islam. They freely looted Christian apocalyptic in search of material they could use when devising their millenarian theories and seem to have firmly believed in the approach of the Hour. In publishing some twenty titles in the space of three years, one Mansur Abdelhakim managed to conquer a considerable corner of the booming market for apocalyptic literature. $\mathrm{He}$ believed that - thanks mainly to the popularity of Christian-Zionist televangelists in the United States - "the American president was able to carry out an old colonial policy under a new concept." The reference to an "old colonial policy" is an allusion to Sayyid Qutb's "crusading spirit" as discussed above; the "new concept" was the crusaders' Christian Zionism supposedly

\footnotetext{
${ }^{34}$ Cook, Contemporary Muslim Apocalyptic Literature, 55-71, 151-80. See also Filiu, Apocalypse in Islam, 9394, 109-10, 117-18, 129-30.

${ }^{35}$ Quoted in Filiu, Apocalypse in Islam, 118.

${ }^{36}$ Quoted in Filiu, Apocalypse in Islam, 107.

${ }^{37}$ Bhatia, Forgetting Osama bin Munqidh, 18.

${ }^{38}$ Filiu, Apocalypse in Islam, 107-10; also see Cook, Contemporary Muslim Apocalyptic Literature, 214-21.
} 
playing out in Iraq where "the American wars [were] religious crusades meant to hasten the coming of the "Messiah" or Jewish Mahdi." 39 This "new Crusader war" wrote another author, was the work of "extremist Christian Zionism" convinced that the "Second Coming of the Messiah" was finally at hand. Many radical authors believe that the Jewish Messiah is the Antichrist prophesied to fall to Jesus's spear before the End of Time. ${ }^{40}$ Almost all radical authors agree that the Antichrist's diabolical supporters are the Jews and their "crusader" allies. Indeed, the "Crusader" occupation of Iraq was no less the work of a "Judeo-Crusader" Antichrist. The front covers of the radical books and pamphlets frequently and graphically illustrate their authors' fixations with this messianic figure. ${ }^{41}$

Thomas Hegghamer's analysis of the content of conversations on jihadist websites leading up to and following the invasion of Iraq in 2003 demonstrates that the notion of a "JewishCrusader" alliance was not the preserve of popular apocalyptic literature. ${ }^{42}$ Abu Mus 'ab alSūrī observed, assimilated and then nourished the millenarian fervour with the online publication in 2004 of his massive, unparalleled treatise on worldwide subversion, The Call to Global Islamic Resistance. ${ }^{43} \mathrm{He}$ believed that "the goal of the call to resistance is resisting the aggression of the Crusader-Zionist campaigns led by America and its Jewish and Crusader allies among the foreign forces of unbelief." 44 "Jihad", he wrote, "is an obligation until the advent of the Hour. The community that fights for what is true and just will be victorious... and it will persevere until the last of its members fights the Antichrist" (whom Abu Mus 'ab al-Sūrī identifies as modern western powers and particularly the United States). ${ }^{45}$ The preeminent apocalyptic theatre was "the country of Shām". Here, the modern Believers will fight against $R \bar{u} m$, the satanic Roman/Byzantine followers of the Dajjāl (the Antichrist, although Dajjāl is sometimes translated as, or referred to as the False Messiah or the Deceiver in IS literature) at al-Malhamah al-Kubrā, the prophesied final great battle of the Islamic apocalypse between the

\footnotetext{
39 According to Abdelhakim, "the American military presence near Israel is intended to help bring about the victory of the Jewish Messiah, but also to confront the Mahdi awaited by Muslims, Sunni and Shi'i alike, whose arrival will precede that of the Jewish Messiah, heir to the throne of David. The American administration and the neoconservatives believe in the biblical prophecies. Both Bushes, father and son, like Reagan before them, are convinced that the awaited Mahdi will appear in the East to do battle with [that is, against] the enemies of Islam and to liberate al-Aqsa Mosque. This is why they have established themselves in Iraq, in the region nearest to where he will appear, in order to be in the best possible position to fight him there." All quotations in Filiu, Apocalypse in Islam, 122.

40 See the appendix.

${ }^{41}$ Cook, Contemporary Muslim Apocalyptic Literature, 184-200; Filiu, Apocalypse in Islam, 107-40 (quotations at 131); Haddad and Smith, "The Anti-Christ and the End of Time", 522-26.

${ }^{42}$ Thomas Hegghamer, "Global Jihadism after the Iraq War", Middle East Journal 60 (2006): 11-32.

${ }^{43}$ Brynjar Lia, Architect of Global Jihad: The Life of Al-Qaeda Strategist Abu Mus'ab Al-Suri (London, 2008). The appendix to Lia's book provides translated excerpts of the treatise. Now defunct jihadist websites published the full treatise. For the similarities in their conception of jihad and its role in the Islamic apocalypse between Mus 'ab al-Sūrī and Abu Muș ab al-Zarqāwī, generally considered the "spiritual father" of IS, see David Cook, "Abu Muș'ab al-Sūrī and Abu Muṣ'ab al-Zarqawī: The Apocalyptic Theorist and the Apocalyptic Practitioner", in Apocalyptic Complex: Perspectives, Histories, Persistence, eds. Nadia Al-Bagdadi, David Marno, and Matthias Riedl (Budapest, 2018), 281-298.

${ }^{44}$ Quoted in McCants, ISIS Apocalypse, 88.

${ }^{45}$ Quoted in Filiu, Apocalypse in Islam, 188. Mus 'ab al-Sūrī's prose here is based on the following hadīth in alSunan of Abū Dāwūd, Book 15, Chapter 851: "The Prophet said: A section of my community will continue to fight for the right and overcome their opponents till the last of them fights with the Antichrist."
} 
forces of good and evil that precedes a messianic confrontation between Jesus and the Antichrist. ${ }^{46}$

The cosmic war between America/Jews/Christian Zionists and the Arab Muslim world seemed inevitable to many people as US troops continued to occupy Iraq (2003-2011) and jihadists increasingly attacked targets around the world. ${ }^{47}$ Publishing his important work in English in 2011, Jean-Pierre Filiu noted that "national and partisan allegiances gave way to an unshakable conviction in an imminent and apocalyptic combat between the three Abrahamic religions". Anti-Semitic conspiracy theories and anti-Christian Zionist rhetoric explained away the Muslim apocalypticists' frustration and rage at events in the modern world. As the theories and rhetoric were increasingly absorbed and turned back against Christian fundamentalists, large sections of the Sunni population in the Near East began to "wallow in the paranoid vision of a world in which Islam's chronic weakness became its surest guarantee of ultimate triumph" at the End of Time. ${ }^{48}$ A poll in 2012 discovered that in seven Muslim-majority countries half or more of all Muslims believed in the imminent approach of the Last Hour and that the Messiah Jesus would return in their lifetime. ${ }^{49}$

The elite leadership of al-Q̄a 'ida, always willing to advance an anti-Semitic worldview that framed conflicts in religious contexts to advance the rhetoric of a Jewish conspiracy aimed at the destruction of Islam and Muslims, was nonetheless reluctant to promote the notion of an immediate apocalyptic resolution to the manifest problem of evil in the world. ${ }^{50}$ And as Filiu noted, no matter how far popular, radical apocalyptic literature may have informed the thinking of ordinary Sunni Muslims, it had yet to exert a great influence on political decision-making. ${ }^{51}$ In June 2014, IS ruptured the collective consciousness of the international community with the rapid capture of Mosul, the second-largest city in Iraq, and the proclamation of its caliphate. As demonstrated below, the cosmic dimension to the "crusader master narrative" mutated again. Armageddon or al-Malhamah al-Kubrā, the final great struggle between good and evil, was close at hand.

\section{The "Crusader Master Narrative" and the Islamic State Apocalypse}

The introduction to issue 1 of Dabiq, published in 1435 Ramadan (29 June-27 July 2014) and titled The Return of the Khilafah, explains why the name Dābiq was chosen as the title of its new flagship magazine:

\footnotetext{
${ }^{46}$ Filiu, Apocalypse in Islam, 189-92. See also the appendix.

${ }^{47}$ See Landes, "Enraged Millennialism", 460-65.

${ }^{48}$ Filiu, Apocalypse in Islam, 121-40.

49 The Pew Forum on Religion and Public Life, The World's Muslims: University and Diversity, accessed 18 November, 2020, https://www.pewforum.org/2012/08/09/the-worlds-muslims-unity-and-diversity-3-articles-offaith/\# ftnref17.

${ }^{50}$ Zeidan, "The Islamist Fundamentalist View", 37; Filiu, Apocalypse in Islam, 184-86; McCants, ISIS Apocalypse, 27-29.

${ }^{51}$ Filiu, Apocalypse in Islam, 140.
} 
The name of the magazine...is taken from the area named Dabiq in the northern countryside of Halab (Aleppo) in Sham. This place was mentioned in a hadith describing some of the events of the Malahim (what is sometimes referred to as Armageddon in English). One of the greatest battles between the Muslims and the crusaders will take place near Dabiq. ${ }^{52}$

The introduction then seeks to validate its claim that Muslims and "crusaders" will fight one of the "greatest battles" of the Malahim (or the Islamic apocalypse) near Dābiq in northern Syria by quoting the prophecy reproduced in the appendix that names the town of Dābiq and predicts the conquest of Constantinople. In its turn, the hadith lends sacred authority to the following words presented immediately after it:

\begin{abstract}
Shaykh Abu Mus'ab az-Zarqawi (rah imahullah) anticipated the expansion of the blessed jihad from Iraq into Sham and linked it to this hadith saying, "The spark has been lit here in Iraq, and its heat will continue to intensify - by Allah's permission - until it burns the crusader armies in Dabiq"... According to the hadith, the area will play a historical role in the battles leading up to the conquests of Constantinople, then Rome. ${ }^{53}$
\end{abstract}

The above quote of Abu Muṣ 'ab al-Zarqāwī, generally considered the "spiritual father" of IS and once head of al-Qā 'ida in Iraq (which morphed into the Islamic State in Iraq four months after Abu Muṣ ' ab al-Zarqāwī was killed on 7 June 2006), adorns the contents' page of every issue of Dabiq. ${ }^{54}$ Such appeals to Islamic scripture are typical in IS propaganda. ${ }^{55}$ By infusing Abu Muṣ 'ab al-Zarqāwī's words with a sense of religious authority, legitimacy and commitment, the authentic hadith essentially ratifies the repeated prediction that "crusader armies" will burn in Dābiq. ${ }^{56}$

Following IS's capture of the town of Dābiq in August 2014, Dabiq 3 reminded its readers why "the name of our magazine was taken from the area named Dābiq in the northern countryside of Halab." It was "due to the significant role it will play during the events of al-Malhamah alKubrā (The Grand Battle) against the crusaders." The magazine then invokes sacred prophecy and unassailable authority again to legitimise its claim that "crusaders" will play a central role in the final great battle of the apocalypse between the diabolical followers of the Antichrist and

52 "Dabiq Magazine", Dabiq 1, Ramadan 1435: 4. Text in round brackets here and elsewhere is as it appears in Dabiq and Rumiyah. The present writer has added text in square brackets to add clarity and meaning.

53 "Dabiq Magazine", Dabiq 1, Ramadan 1435: 5. Shām refers to Syria in a broad historical sense (including Palestine, Lebanon and Jordan). Location of the Roman invasion and defeat at Dābiq, the appearance of the Antichrist and then Jesus's descent from heaven, as well as the Messiah's subsequent execution of the Dajjāl and the destruction of his followers, Shām is a region central to the Islamic apocalypse. As did Abu Mus 'ab al-Sūrī, IS propagandists considered Shäm the apocalyptic theatre par excellence. See McCants, ISIS Apocalypse, 106. See the "Amāq Cycle" authentic hadìth appended to the article for the centrality of Shàm in the Islamic apocalypse. ${ }^{54}$ On Abu Muș 'ab al- Zarqāwī, see McCants, ISIS Apocalypse, 7-15.

${ }^{55}$ Jennifer Boutz, Hannah Benninger, and Alia Lancaster, "Exploiting the Prophet's Authority: How Islamic State Propaganda Uses Hadith Quotation to Assert Legitimacy”, Studies in Conflict \& Terrorism 42 (2019): 972-96.

56 IS's first "commander of the faithful," Abū "Umar al-Baghdādī, quoted the same prophecy in his announcements: McCants, ISIS Apocalypse, 102-03. 
Jesus and his supporters by quoting once more the authentic hadìth in the "Amāq Cycle" that mentions the town of Dābiq. ${ }^{57}$

The next issue of the group's flagship magazine, Dabiq 4, is entitled "The Failed Crusade". It provides the fullest exposition on IS's conception of the so-called "crusade" throughout the group's literature, and it is worth a close exposition to reveal the techniques that turned modern "crusaders" into the supporters of the Antichrist identified in the seventh-century hadith. ${ }^{58}$ Under the (sub)title "The Prophecies regarding the Roman Crusaders", the authentic tradition that mentions Dābiq is initially reproduced. The hadìth is followed on the next line of the magazine by a variant from the "Amāq Cycle" that predicts an episode of Roman treachery (as also noted in the "Portents of the Hour" tradition appended to the article) heralding the cosmic war and the final great battle of the apocalypse:

\begin{abstract}
Allah's Messenger (sallallāhu 'alayhi wa sallam) said, "You will have a treaty of security with the Romans until you both fight an enemy beyond them. ${ }^{59}$ And you will be victorious, you will gain war booty, and you will achieve such without losses. Thereafter you will return until you lodge at a pastureland full of rocky mounds. A man from the Roman Christians will then raise the cross. He will say, 'The cross has prevailed!' A man from the Muslims will then say, 'Rather Allah has prevailed,' and then he will angrily rise and crush the cross, which is not at a distance from him. Then the Romans will betray the treaty by rising against the breaker of the cross and striking his neck. The Muslims will then rise and rush to their arms. They will then battle. Allah will bless this party of Muslims with shahādah [martyrdom]. The Romans will say to the Roman leader, 'We are sufficient for you against the Arabs.' They will then gather for the Malhamah (the grand battle before the Hour). They will come for you under eighty banners, with each banner there will be twelve thousand people."

sahīh - reported by Imām Ahmad, Abū Dāwūd, Ibn Mājah, Ibn Hibbān, and Al-Hākim on the authority of Dhī Mikhmar. ${ }^{60}$
\end{abstract}

\footnotetext{
57 “Islamic State Reports”, Dabiq 3, Shawwal 1435: 15.

58 See the appendix.

${ }^{59}$ Variants of this hadith provide valuable detail to the basic narrative here, including the identity of the joint Muslim and Roman target "beyond" the latter: see David Cook, Studies in Muslim Apocalyptic (Princeton, NJ, 2002), 49-52.

60 "Reflections on the Final Crusade", Dabiq 4, Dhul Hijjah 1435: 33. The authorities cited here in Dabiq 4 are Abū 'Abdillāh Aḥmad ibn Muhammad ibn Hanbal al-Shaybānī (164-241/780-855), founder of the Hanbali school of Sunni jurisprudence and one of the four major orthodox legal schools of Sunni Islam. His collection of hadith is known simply as the Musnad. See Christopher Melchert, Ahmad ibn Hanbal (Oxford, 2006). Abū Dāwūd Sulaymān b. al-Ash 'ath b. Isḥāq b. Bashīr b. Shaddād b. 'Amr b. 'Imrān (or 'Āmir) al-Azdī al-Sijistānī (202$75 / 817$ or 818-89). Whilst not as revered as Bukhārī’s and Muslim's compilations of hadīth, Abū Dāwūd's collection, simply entitled al-Sunan, is generally ranked third of the six canonical collections of prophetic traditions. See Christopher Melchert, “Abū Dāwūd al-Sijistān̄̄”, in Encyclopaedia of Islam Three, eds. Kate Fleet, Gudrun Kramer, Denis Matringe, John Nawas, and Everett Rowson, DOI:10.1163/1573-3912_ei3_SIM_0024. Abu Hatim Muhammad ibn Hibbān ibn Ahmad al-Tamimi al-Busti (c. 270-354/c. 883-965). Ib̄nn Hī̄bān's collection of hadīth is called al-Musnad al-șahīh 'ala 'l-taḳāsìm wa 'l-anwā': J. W. Fuck, "Ibn Hibbān", in Encyclopaedia of Islam Two, eds. P. Bearman, Th. Bianquis, C. E. Bosworth, E. van Donzel, and W. P. Heinrichs, DOI:10.1163/1573-3912_islam_SIM_3199. Also see C. Brockelmann, "Ibn Hibbān”, in Encyclopaedia of Islam One, eds. M. Th. Houtsma, T. W. Arnold, R. Basset, and R. Hartmann, DOI:10.1163/2214-871X_ei1_SIM_3007.
} 
The authentic prophecy reproduced in the appendix that predicts the mustering of the forces of good (Muslims) and evil (Romans) before al-Malhamah al-Kubrā, the ensuing great battle before the conquest of Constantinople, the coming of the Dajjall, and the mission of the scouting party of ten horsemen begins on the very next line in the magazine. ${ }^{61}$ Following these three "Prophecies regarding the Roman Crusaders" in Dabiq 4, the author of the feature goes on to highlight, synthesise and explain the signs of the coming Hour identified in these traditions and others from the "Amāq Cycle" reproduced in the appendix:

The Romans will commit treachery by raising the cross and killing a Muslim. This will lead to the continuation of the war between the Muslims and the Romans. They will demand access to those who enslaved some of them or the former captives themselves who accepted Islam so as to fight them. This enslavement will have taken place either before the signing of the truce or after the treachery, and Allah knows best. These events all lead up to the final, greatest, and bloodiest battle - alMalhamah al- Kubrā - between the Muslims and the Romans prior to the appearance of the Dajjāl and the descent of al-Masīh. This battle ends the era of the Roman Christians, as the Muslims will then advance upon Constantinople and thereafter Rome, to conquer the two cities and raise the flag of the Khilāfah over them. ${ }^{62}$

Immediately after explaining how the Romans's treachery in "raising the cross" and their defeat in the consequent al-Malhamah al-Kubrā near Dābiq usher in the messianic confrontation between the Dajjāl and al-Masīh Jesus before the universal reign of Islam, is a section on "The Islamic State Founders on the Signs of the Hour":

They [the founders] knew that the efforts of the mujahidin in Iraq would lead up to the Malhamah...Shaykh Abū Mus'ab az-Zarqāwī (rahimahullāh) said, "The spark has been lit here in Iraq, and its heat will continue to intensify - by Allah's permission - until it burns the crusader armies in Dābiq".

Ayna Ahlul Murū'āt ${ }^{63}$

Note the use of rahimahullah ("Allah have mercy upon him") here, a phrase often used in Islamic literature after mentioning an Islamic authority, and the citation to an (unknown) authority (Ayna Ahlul Murū'āt) following Abu Muṣ 'ab al-Zarqāwī's prediction. Hadìth have their authority cited in the same manner. To emphasise the IS's founders' "firāsah (perception/insight) and deep understanding" of millenarian prophecy and the forthcoming

Abū 'Abd Allāh Ibn al-Bayyi', known as al-Hākim al-Naysābūrī (331-405/933-1014). His collection of hadīth is al-Mustadrak 'ala 'l-Ṣaḥịhayn: J. Robson, "al-Hākim al-Naysābūrī”, in Encyclopaedia of Islam Two, DOI:10.1163/1573-3912_islam_SIM_2638. Abū 'Abdallāh Muhammad b. Yazīd Ibn Mājah al-Qazwīn̄̄ (209/824-5-273/887-8). Ibn Mājah's collection of hadīth, simply entitled al-Sunan, is widely considered the sixth of the six canonical collections of prophetic traditions: Christopher Melchert, "Ibn Māja", in Encyclopaedia of Islam Three, DOI:10.1163/1573-3912_ei3_COM_30647.

61 "Reflections on the Final Crusade", Dabiq 4, Dhul Hijjah 1435: 34.

62 "Reflections on the Final Crusade", Dabiq 4, Dhul Hijjah 1435: 35.

63 "Reflections on the Final Crusade", Dabiq 4, Dhul Hijjah 1435: 35. 
Malhamah al-Kubrā, the feature implicitly compares Abū 'Umar al-Baghdādī, IS's first "commander of the faithful", to no less a person than "Shaykhul-Istām Ibn Taymiyyah (rahimahullāh)". ${ }^{64}$ A series of Ibn Taymiyyah's predictions, which supposedly transpired, are then quoted; these too have their authority cited in the manner of Abu Muṣ 'ab al-Zarqāwī's prediction and the hadīth. Dabiq 4 next informs its audience that "after reading the above words of Shaykhul-Islām Ibn Taymiyyah, no one should be shocked to hear the conviction and certainty of the mujahidin leadership regarding Allah's promise and the Messenger's prophecies (sallallāhu 'alayhi wa sallam)", ${ }^{65}$

The next words of the same feature in Dabiq 4 are the subtitle "Shaykh 'Adnani's Words on the Crusade", and the following excerpt from a transcription of a speech given by Abū Muḥammad al-'Adnānī, IS's second-most senior leader when killed by a US airstrike in August 2016:

O soldiers of the Islamic State, be ready for the final campaign of the crusaders. Yes, by Allah's will, it will be the final one. Thereafter, we will raid them by Allah's permission and they will not raid us...And so we promise you (crusaders) by Allah's permission that this campaign will be your final campaign. It will be broken and defeated, just as all your previous campaigns were broken and defeated, except that this time we will raid you thereafter, and you will never raid us. We will conquer your Rome, break your crosses, and enslave your women, by the permission of Allah, the Exalted. This is His promise to us; He is glorified and $\mathrm{He}$ does not fail in His promise. If we do not reach that time, then our children and grandchildren will reach it, and they will sell your sons as slaves at the slave market. ${ }^{66}$

Abū Muḥammad al-'Adnānī expressed no doubt that the "weak, pitiful, and abortive crusade will be the final one encompassing the eventual truce and crusader treachery leading up to alMalhamah al-Kubrā." "So", Abū Muḥammad al-“Adnān̄̄ is quoted as saying,

Mobilize your forces, $\mathrm{O}$ crusaders. Mobilize your forces, roar with thunder, threaten whom you want, plot, arm your troops, prepare yourselves, strike, kill, and destroy us. This will not avail you. You will be defeated. This will not avail you, for our Lord, the Mighty, the Prevailing, has promised us with our victory and your defeat.

\footnotetext{
${ }^{64}$ The unrivalled champion of Hanbali literalism whose late thirteenth/early fourteenth-century theological works form the founding basis of IS's Salafi orientation: Quintan Wiktorowicz, “A Genealogy of Radical Islam", Studies in Conflict \& Terrorism 28 (2005): 75-97; Patrick Sookhdeo, Global Jihad: The Future in the Face of Militant Islam (Vienna, VA, 2007), 76-77. Haroro J. Ingham notes that Osama bin Laden likewise used to cite Ibn Tamiyyah in a process that tapped into the "transformative charisma" of the medieval theologian and enabled the al-Qā ida leader to stake a claim amongst a lineage of revered Islamic heroes; see Haroro J. Ingram, The Charismatic Leadership Phenomenon in Radical and Militant Islamism (Farnham, 2013), 93-94. Since its inception the leaders of IS have infused the ideology of Salafi-Jihadism with a hybrid of other extreme Islamic ideologies, see Djallil Lounnas, "The Failed Ideological Hybridization of the Islamic State", Studies in Conflict \& Terrorism (2020):DOI:10.1080/1057610X.2020.1759186.

65 "Reflections on the Final Crusade", Dabiq 4, Dhul Hijjah 1435: 37.

66 "Reflections on the Final Crusade", Dabiq 4, Dhul Hijjah 1435: 37.
} 
"This certainty is the one that should pulse in the heart of every mujāhid from the Islamic State and every supporter outside until he fights the Roman crusaders near Dābiq." ${ }^{\circ 7}$

Note in Abū Muhammad al-'Adnān̄̄'s supposed words the allusions to the "Amāq Cycle" traditions. The variant tradition quoted above notes the truce between Muslims and Romans, the treachery of a Roman "raising the cross" and the subsequent murder of the "breaker of the cross" leading to the final great battle between the forces of good and evil that is a harbinger of the approaching eschaton. Prophetic reports have Muhammad promising his early Believers that they would conquer the Romans near Dābiq, and informing them that following the Messiah's assassination of the Antichrist, Jesus would go on to break the Christian crosses, eventually heralding universal Islamic rule before the End of Time. ${ }^{68}$ And Abū Muhammad al"Adnānī could claim "with conviction and certainty" that the "crusaders" were engaged in their "final campaign" against Muslims because he, like Abū 'Umar al-Baghdādī, had "firāsah and deep understanding" of millenarian prophecy and the forthcoming Malhamah al- Kubrā.

Let us take stock of what is happening here in Dabiq 4. The magazine splices allusions to, and direct quotations from hadith and prestigious scholars from the Islamic past with its own messages presented in a comparable style and similar words to Islamic scripture. The reader encounters the three "Prophecies regarding the Roman Crusaders", then the words of "The Islamic State Founders on the Signs of the Hour" and the comparison of Abu 'Umar alBaghdādī with "Shaykhul-Islām Ibn Taymiyyah", and then in the very next breath "Shaykh 'Adnani's Words on the Crusade". This interweaving of sacred prophecies, historical Islamic authorities and the declarations of Islamic State's senior leadership not only added credibility, legitimacy and the air of authenticity to the leadership's messages; the practice gave those messages concerning the diabolical "crusaders" and their supposed role in the Malahim the appearance of being foretold. ${ }^{69}$ The Islamic State soldiers were the prophesied agents of divine will and the seventh-century Roman supporters of the Antichrist were transformed into modernday "crusaders".

In Safar 1438 (1 November-30 November 2016), the month following the re-capture of Dābiq by Turkish-backed rebels, Rumiyah 3 elucidated for its readers why IS had not won the foretold battle at Dābiq:

The cross-worshipers and their murtadd [apostate] allies did not know - and how could they possibly know - that the Major Malhamah of Dabiq will be preceded by great events from the minor signs of the Hour, events the believers performing ribat

\footnotetext{
67 "Reflections on the Final Crusade", Dabiq 4, Dhul Hijjah 1435: 37.

${ }^{68}$ See the appendix.

${ }^{69}$ Compare with Haroro J. Ingram, “An Analysis of Inspire and Dabiq: Lessons from aqap and Islamic State's Propaganda War", Studies in Conflict \& Terrorism 40 (2016): 357-75; and Haroro J. Ingram, "An Analysis of Islamic State's Dabiq Magazine”, Australian Journal of Political Science 51 (2016): 458-477.
} 
in their trenches know. They are events of which the truthful, trustworthy prophet informed in the ahadith of the tribulations, the malahim, and the signs of the Hour. ${ }^{70}$

Prophecies quoted in the appendix, as well as the prophecy quoted above that collectively foretell the Romans' treachery and mustering of forces, the cosmic encounters presaging the alMalhamah al- Kubrä, the conquest of Constantinople and the Antichrist's intervention, the scouting party of ten Muslim horsemen and the Antichrist's messianic confrontation with Jesus, son of Mary, are then reproduced. Unassailable, sacred authority is therefore again invoked, this time to explain why:

The great events unfolding now in northern Sham - in Dabiq and its surroundings - are but signs of the coming malahim, inshaallah. These great events will force the Crusaders - sooner or later - to accept the terms of the Jama'ah of the Muslims, a truce that is precedent to the Major Malhamah of Dabiq. ${ }^{71}$

According to Rumiyah 3, the loss of Dābiq in October 2016 was but one of the prophesied signs of strife and tribulation presaging the eschaton; other signs had yet to occur that were harbingers of the "crusaders" destruction at al-Malhamah al- Kubrā. The modern believers, now performing ribat (or waiting in anticipation of fighting the enemy) in the trenches (an allusion to the Battle of Trenches in 627) know this to the case. The "cross worshippers" and "crusaders" had yet to make a truce with the "Jama'ah of the Muslims," that is, the IS organisation; or, in the words of the preferred hadith quoted above to which this statement alludes, Muslims had yet to "have a treaty of security with the Romans". The recent events at Dābiq were not to be equated with the prophesied last great battle between the Muslims and "crusaders" before the End of Time. Nonetheless, as IS informed its readers, other prophecies had transpired, and Muslims were now self-evidently living through the prophesied End Times. Given the incontestable truth of the prophecies, the self-proclaimed credibility and authenticity of the IS leadership's messages, and indeed its ability to predict the future in the manner of Ibn Taymiyyah, IS propaganda could reassure its supporters that they were in the process of immanentizing the eschaton and that other signs foretelling it would soon occur:

This war of attack and withdrawal occurring in Dabiq and its surrounding areas the minor battle of Dabiq - will inevitably lead to the Major Malhamah of Dabiq, even if a withdrawal were to precede it by Allah's decree. Indeed, the Malhamah will come about after that which Allah and His Messenger have promised is materialized, including the treaty between the Muslims and the Romans followed by the Romans' betrayal that leads to the Major Malhamah of Dabiq. Thereafter, will come the certain conquest of Constantinople and then the city of Rome. ${ }^{72}$

\footnotetext{
70 "Towards the major Malhamah of Dabiq", Rumiyah 3, Safar 1438: 25.

71 "Towards the major Malhamah of Dabiq", Rumiyah 3, Safar 1438: 25.

72 "Towards the major Malhamah of Dabiq", Rumiyah 3, Safar 1438: 25.
} 
IS propaganda typically employs the proper nouns "Rome" and "Romans" in two main ways: as metonymical motifs presenting Christianity, Europe and the United States as some sort of sinful, homogenous religio-political (and anti-Islamic) entity once led by George W. Bush, the "Caesar of Rome"; and less frequently, with reference to the ancient city of Rome, the Vatican enclave and their inhabitants. The blurring of symbolic, metonymic and synecdoche meanings of "Rome" and "Romans" acted in different ways and served several purposes. References to the capital of the ancient Roman Empire recalled the understanding that "Romans" were the seventh-century satanic enemies of Islam still destined to play an eschatological role in the coming of the Hour. The IS propagandists frequently overlooked that the capital of the Roman Empire was Constantinople in the seventh century. At the same time, "Rome" conceived and presented metonymically allowed militant Islamist propagandists to update and interpret the authentic hadīth with their references to "Romans" in ways that placed IS's modern "Roman Crusader" enemies within the "Amāq Cycle" traditions. ${ }^{73}$ Interestingly, the bishops of Rome and the Vatican feature as targets in the apocalyptic scenarios imagined in the popular radical messianic literature flooding out of Egypt and elsewhere from the late 1990s onwards. ${ }^{74}$ In such literature, as well as in IS propaganda, the references to "Rome" and "Romans" invoke the idea that Christians, the Vatican and the Supreme Pontiff of Rome, head of the Roman Church, were and always have been eschatological targets for jihadist violence as legitimised by sacred tradition. It mattered little to the IS propagandists and the authors of the radical messianic literature that the Vatican city-state did not come into being until 1929, nor that the short-lived popes of the seventh-century, who do not feature in the canonical hadith, were of no concern to Arabs in the same period. The propagandists' debt here to radical, not classical Muslim apocalyptic seems clear.

The warping and shading of symbolic, metonymic and synecdoche meanings of the proper nouns "Rome" and "Romans" are witnessed on the front or contents' page of every issue of Rumiyah. The very title of the magazine invokes the prophesied conquest of "Rome" and its role in the IS apocalypse in the same way as the title of the Dabiq magazine invoked the impending Grand Battle of the Malahim. Similarly, the front or contents' page of every issue of Rumiyah carries a quote from a former leader of IS that alludes to an authentic hadith in the "Amāq Cycle”. Abu Hamza al-Muhajir, head of al-Qā 'ida in Iraq after Abu Mus'ab al-Zarqāwī (whose prediction that the "crusader armies" will burn in Dābiq adorns the contents' page of every issue of Dabiq) and later IS's Minister of War, is quoted as saying: "O muwahhidin [believers in tawhid: the absolute oneness of Allah], rejoice, for by Allah, we will not rest from our jihad except beneath the olive trees of Rumiyah (Rome)." The victorious Muslims in the authentic Amāq tradition alluded to here will actually rest beneath the olive trees of Constantinople, and the Amāq hadìth usually quoted in IS literature do not refer to the city of Rome but to seventh-century Rüm, that is, Romans (or Byzantines). ${ }^{75}$ Precision and historical

\footnotetext{
${ }^{73}$ See also Francesco Marone and Marco Olimpio, "We Will Conquer Your Rome": Italy and the Vatican in the Islamic State's Propaganda", Studies in Conflict \& Terrorism (2020): DOI:10.1080/1057610X.2020.1776952.

${ }^{74}$ See, for example, Filiu, Apocalypse in Islam, 128.

${ }^{75} R \bar{u} m$ is often translated as "Rome" and interpreted as the city of Rome. The literal translation of Rüm is "Romans", while a more useful translation might be "Byzantines": during the period when the canonical collections of hadīth were compiled the pronoun Rüm usually denoted the Christian peoples of the (eastern)
} 
accuracy yield to propaganda in IS's flagship magazines. The repeated prediction is employed on the front page of Rumiyah to infuse the words of the IS senior leadership with sacred authority that proclaims the conquest of demonic "Rome" and "Romans" - the city? - the western world? - Christianity? - Christian Zionism? - evil? - crusaders? as a sign foretelling the arrival of the Last Hour.

Scholars have discussed the blurring of other unrelated, historical phenomena in IS propaganda, a process that Alastair Reed and Jennifer Dowling have termed "temporal stretching" ${ }^{76}$ Dabiq and Rumiyah make specific references and vague allusions that place IS and its leadership, soldiers and suicide operatives in an imagined temporal continuum with the celebrated, transhistorical heroes of the Islamic past and especially with the companions of the Prophet. ${ }^{77}$ Similarly, according to IS propagandists, seventh-century Romans/Byzantines, Latin Christians of the central Middle Ages, Europeans of the colonial era and those somehow involved in the creation of the state of Israel, as well as any person of any nation involved directly or indirectly in combatting IS were all "crusaders". ${ }^{78}$ The modern conflicts between the "crusaders" and IS were thus transformed into the latest stage of an enduring state of warfare between the "Roman Crusaders" and the heirs of the earliest Believers. As Rumiyah 6 claimed: "this blessed jihad...has not stopped since Allah's Messenger and his noble companions commenced it." Islamic State proclaimed merely to represent Islam "today in these current rounds of the "mujahidin's war" against its various enemies "at the head of which are the Crusader nations of the West". ${ }^{79}$ The group's enemies had allegedly "thrust their claws into the Ummah's body for centuries, so it [was] time that those claws [were] pulled out and those hands [were] severed". ${ }^{80}$ The temporal stretching of unrelated historical phenomena allowed IS to cast its warriors in the same mould as Islamic heroes through history. Allah's Mujahedeen fighting in an unbroken line since the days of the Prophet, reversing and then decisively putting an end to the eternal "crusade" against Islam. This was to be "the final campaign of the crusaders". 81

Roman Empire, more commonly referred to as Byzantium. See Cook, Studies in Muslim Apocalyptic, 9; Nadia El-Cheikh and C. E. Bosworth, "Rūm", in Encyclopaedia of Islam Two, DOI:10.1163/15733912_islam_COM_0939. See also Koray Durak, "Who Are the Romans? The Definition of Bilād al-Rüm (Land of the Romans) in Medieval Islamic Geographies", Journal of Intercultural Studies 31 (2010): 285-98.

${ }^{76}$ Jason T. Roche, Islamic State and the Appropriation of the Crusades - a Medieval Historian's Take, accessed 18 June 2020, https://theconversation.com/islamic-state-and-theappropriation-of-the-crusades-a-medievalhistorians-take-75319; Reed and Dowling, "The Role of Historical Narratives in Extremist Propaganda", 87-88.

${ }^{77}$ See, for example, "The Response to the Call of the Prophet", Dabiq 15, Shawwal 1437: 14-19; "Paths to Victory - Part 2", Rumiyah 3, Safar 1438: 21-23; "Leaders of the Murabit Emirate", Rumiyah 5, Rabi Al-Akhar 1438: 30-33; "Examples of the Sahabah's Eagerness to Attain Shahadah", Rumiyah 6, Jumada Al-Awwal 1438: 40-43; "It Will Be a Fire that Burns the Cross and its People in Raqqah", Rumiyah 12, Dhul Qadah 1438: 35. See also Samuel P. Perry, and Jerry Mark Long, “'Why Would Anyone Sell Paradise?': The Islamic State in Iraq and the Making of a Martyr", Southern Communication Journal 81 (2016): 1-17; Jakob Skovgaard-Peterson, "Heirs of Abu Bakr: On the Ideology and Conception of History in al-Qaeda and Islamic State", Connections: The Quarterly Journal 16 (2017): 25-36; Pieter Nanninga, “Among the Believers Are Men': How Islamic State uses EarlyIslamic Traditions to Shape its Martyr Biographies”, Numen 65 (2018): 165-84.

${ }^{78}$ See, for example, "The Extinction of the Grey Zone", Dabiq 7, Rabi Al-Akhar 1436: 54-58; "Be Patient, For Indeed the Promise of Allah is True", Rumiyah 9, Shaban 1438: 20-23; “And Fight the Mushrikin Collectively", Rumiyah 8, Rajab 1438: 39.

79 “And Do Not Weaken in Pursuing the Enemy”, Rumiyah 6, Jumada Al-Awwal 1438: 10.

80 "Be Patient, For Indeed the Promise of Allah is True", Rumiyah 9, Shaban 1438: 31.

${ }^{81}$ Compare with Alexander Kirke, "Violence and Political Myth: Radicalizing Believers in the Pages of Inspire Magazine", International Political Sociology 9 (2015): 283-298. 


\section{Conclusion}

As has been argued here for the first time, in collapsing an imagined past with an imaginary present, IS's flagship magazines referred to the actual crusades or crusaders on just two occasions and relied instead on the western imperialist and anti-Islamic connotations that the words "crusade" and "crusaders" held for their readership. But the words were not mere metonymic proxies for the "crusader master narrative" as discussed by Halverson. The group's propagandists stretched the "crusader master narrative" invoked and developed by Sayyid Qutb and Osama bin Laden back over 400 years before the First Crusade (1095-99) and infused it with millenarian ideas, sacred prophecy, Islamic authority, and the professed legitimacy and prophetic insight of IS's senior leadership. The re-framed and re-casted narrative offered the group's supporters another connection to and continuous identity with the early Believers. They were also taught the incontestable truth of the "Amāq Cycle" authentic hadīth. They too were told they were living through the apocalypse and immanentizing the eschaton. ${ }^{82}$ IS's soldiers were the new Muslim champions in the enduring cosmic war against the Antichrist and its "crusader" allies. "And this will be the case until their tăghüt [idolatress] cross is broken by the Masīh 'Īsa" [the Messiah, Jesus]." ${ }^{83}$ As an IS spokesman declared of his fellow soldiers as early as 2013: "we will not lay down this flag until we present it to Jesus, the son of Mariam, and the last of us fights the Deceiver." 84

IS's leadership and propagandists clearly exploited the widespread interest in radical apocalyptic literature with its fixations on the foretold cosmic war and the messianic figures in the "Amāq Cycle". On occasions, the magazines appear to have drawn influences directly from the radical literature. That literature, which borrowed heavily from Jewish and Christian apocalypses to create a radical apocalyptic landscape within the space of three decades, may have been more influential than there has been space to argue for here. This article has shown how IS propaganda makes repeated references to the Christian cross, invoking the sense that the group's enemies were at war with the Mujahedeen for religious rather than worldly reasons and (especially) recalling the hadith referring to Jesus, son of Mary, breaking the cross and ushering in the universal reign of Islam. Dabiq 15 is actually entitled "Break the Cross" in direct reference to the hadith. Much of this issue pits the "cross-worshippers" as the enemies of Islam, and interestingly, decries the alleged falsehoods and failings of Christianity and IS's Christian opponents. In the process, the issue has recourse to Jewish and Christian scripture, echoing the practices found in the radical messianic literature with its refutation of Christian Zionism. The message is simple in Dabiq 15 and follows the radical authors' lesson to the non-Muslim people of the western world: Islam is the superior religion and Christians should convert if they wished

\footnotetext{
${ }^{82}$ The earliest Believers looked forward to the imminent end of the world and were taught that jihad would immanentize the eschaton in their lifetime. For a good recent examination of this early period, see Stephen J. Shoemaker, The Apocalypse of Empire: Imperial Eschatology in Late Antiquity and Early Islam (Philadelphia, PA, 2018), 124-79.

83 "Reflections on the Final Crusade", Dabiq 4, Dhul Hijjah 1435: 32-37 (here 32).

${ }^{84}$ McCants, ISIS Apocalypse, 106.
} 
to be saved. Jesus is the champion of Islam, and Muslims - not Christians - will hold the dominant position in the world come the Last Hour. ${ }^{85}$ Are there other undiscovered elements of IS propaganda that one could read as refutations of Christian Zionism? Is this yet another undiscovered layer to IS's re-framed and re-casted "crusader master narrative"? ${ }^{86}$

In any case, there is little reason to doubt that IS propaganda manipulated and combined a culturally embedded sense of Islamic history with a heady, potent mixture of classical and radical apocalyptic, and real and supposed Islamic authority, both sacred and profane. As this article's novel exposition of the group's international flagship magazines has now established, by tapping into the widespread belief in the approach of the Last Hour, IS attempted to change the "crusader master narrative" by giving "crusaders" and their "crusade" integral roles in Islamic sacred history and the impending Malahim.

\section{Appendix}

\section{The "Portents of the Hour" and "Amāq Cycle" Authentic Hadīth}

Frequent references and allusions to sacred texts augmented the Islamic State's well-known claim to be pursuing the eschaton and the cataclysmic conclusion of time. ${ }^{87}$ The Qur'an is rich in descriptions of the Final Judgement, but it provides few clues regarding the apocalyptic calendar and the omens and signs foretelling the coming of the Last Hour. Instead, the prophetic reports, the oral "traditions" of the Prophet Muhammed, collectively known as hadīth (literally "news" or "reports" of the Prophet and his companions), completed the vision, narrative and framework of the Islamic apocalypse. ${ }^{88}$

Two sets of sahịh ("authentic" or "genuine") traditions were particularly important to the conception of crusades and crusaders in IS propaganda: the "Portents of the Hour" traditions and another set of historical apocalypses known collectively as the "Amāq Cycle" ${ }^{89}$ In the first

\footnotetext{
85 "Break the Cross", Dabiq 15, Shawwal 1437: 53-62; "By the Sword", Dabiq 15, Shawwal 1437: 78-80.

86 The notion of George W. Bush, "the Caesar of Rome", (considered by Mansur Abdelhakim and many other radical authors to be a Christian Zionist) raising "the cross" in the manner of the Roman soldier prophesied to ignite the cosmic war between good and evil could certainly be read this way.

${ }^{87}$ William McCants, The ISIS Apocalypse: The History, Strategy, and Doomsday Vision of the Islamic State (New York, 2015); J. M. Berger, "The Metronome of Apocalyptic Time: Social Media as Carrier Wave for Millenarian Contagion", Perspectives on Terrorism 9 (2015): 61-71; James Fromson, and Steven Simon, "ISIS: The Dubious Paradise of Apocalypse Now", Survival 57 (2015): 7-56; Scott Philip Segrest, "ISIS's Will to Apocalypse", Politics, Religion and Ideology 17 (2016): 352-69; Mark Juergensmeyer, "How Cosmic War Ends: The Case of Isis", Numen 65 (2018): 125-40; Jennifer Boutz, Hannah Benninger, and Alia Lancaster, "Exploiting the Prophet's Authority: How Islamic State Propaganda Uses Hadith Quotation to Assert Legitimacy", Studies in Conflict \& Terrorism 42 (2019): 972-996.

${ }^{88}$ The term hadith is both a collective noun, referring to the corpus of the Prophet Muhammad's oral traditions, and a singular, countable noun referring to individual prophetic reports.

${ }^{89}$ The definitive anthologies of hadīth were compiled during the third century ah/ninth century ce. The two most respected collections of authentic hadìth are the works of Muhammad ibn Ismail al-Bukhārī (194/810-256/870) and his student, Muslim ibn al-Hajjāj (206/815-261/875), who are known jointly as al-ṣahịhayn ("the two authentic ones"). Both of their collections are known simply as Al-Sahịh. See Jonathan Brown, The Canonization
} 
set of hadīth, a series of historical events, usually six, indicate the coming of the Hour. For example, the Prophet said:

Count six signs that indicate the approach of the Hour: my death; the conquest of Jerusalem; a plague that will afflict you (and kill you in great numbers) as the plague that afflicts sheep; the increase of wealth to such an extent that even if one is given one hundred Dinars, he will not be satisfied; then an affliction [civil war] which no Arab house will escape; and then a truce between you and Bani al-Asfar (i.e. the Byzantines), who will betray you and attack you under eighty flags. Under each flag will be twelve thousand soldiers. ${ }^{90}$

The seventh-century prophecy that the Byzantines, or rather, the people of the (eastern) Roman Empire will betray a truce with the Prophet's early Believers and then attack them opens towards the authentic "Amāq Cycle" apocalyptic traditions. ${ }^{91}$ The following hadith indicates the reason why the Romans will betray their Muslim allies, that is, over the share of the spoils of war, and also predicts the mustering of a Roman army as a harbinger of the apocalypse. The tradition then outlines the subsequent cosmic encounters between the Romans and the early Believers that will lead to the final great battle before the Last Hour, al-Malhamah al-Kubrā:

The Last Hour will not come until shares of inheritance are not distributed and there is no rejoicing over spoils of war. Then [the Prophet] said, pointing towards Syria [Shām] with the gesture of his hand like this: the enemy shall muster strength against Muslims and the Muslims will muster strength against them. I said: You mean the [Romans, al-Rüm] ${ }^{92}$ And he said: Yes, and there will be a terrible fight

of al-Bukhārī and Muslim: The Formation and Function of the Sunni Hadīth Canon (Leiden, 2013). Many of the hadith quoted in, or alluded to in IS literature are identifiable through clues and indicators in the content and context of the quote and associated text. Allusions to other hadith are embedded in IS literature, with little or no indication as to the specific hadìth in question. Our concern here is only with the hadith collected by al-ṣahīhayn that IS employed most clearly and consistently in its conception of crusades and crusaders in its flagship magazines, Dabiq and Rumiyah. David Cook, Jean-Pierre Filiu and Stephen J. Shoemaker discuss the hadìth, their variants and other apocalypses in the "Amāq Cycle", as well as the possible contexts in which they were first recorded. See David Cook, Studies in Muslim Apocalyptic (Darwin, 2002), 49-52; Jean-Pierre Filiu, Apocalypse in Islam, trans. M. B. DeBevoise (Berkeley and Los Angeles, 2011), 18-29; Stephen J. Shoemaker, The Apocalypse of Empire: Imperial Eschatology in Late Antiquity and Early Islam (Philadelphia, PA, 2018), 17079.

90 Șahīh al-Bukhārī, Book 38, Chapter 15. For reasons of accessibility, and unless stated otherwise, only the pertinent parts of each hadith are quoted here and each hadith is taken from sunnah.com, a well-respected and freely accessible website housing collections of hadith in English with parallel Arabic text. The hadith book and chapter numbers cited here follow those employed on the website. Similarly, text in round brackets quoted here and elsewhere is at it appears in Sunnah.com. On occasions, the present writer has added text in square brackets and made slight adjustments to grammar and syntax that add clarity and meaning and in no way change the sense or tone of the hadìth.

${ }^{91}$ The $A m \bar{a} q$ are the valleys of northern Syria between Hims and the Taurus Mountains. They formed the staging ground for Arab-Islamic raids into Anatolia during the Umayyad period and witnessed many clashes between the Byzantine and Arab-Islamic armies; see Cook, Studies in Muslim Apocalyptic, 49-52.

${ }_{92}$ As is the case here in Sunnah.com and as is often the case elsewhere, Shām is translated as Syria, although Shām in the canonical hadīth referred to Syria in a broad historical sense (including Palestine, Lebanon and Jordan). Similarly, Rüm is often translated as "Rome" as it is here in Sunnah.com, and the word is often interpreted to refer to the city of Rome. The literal translation of Rum is "Romans", while a more useful translation might be "Byzantines": during the period when the canonical collections of hadìth were compiled the pronoun Rüm usually 
and the Muslims will prepare a detachment (for fighting unto death) which will not return but victorious. They will fight until the night intervenes; both sides will return without being victorious and both will be wiped out. The Muslims will again prepare a detachment for fighting unto death so that they may not return but victorious. On the fourth day, a new detachment out of the remnant of the Muslims will be prepared and Allah will decree that the enemy should be routed. And they will fight such a fight the like of which will not have been seen, so much so that even if a bird were to pass their flanks, it would fall down dead before reaching the end of them. (There will be such a large-scale massacre) that when counting will be done, (only) one out of a hundred men related to one another will be found alive. ${ }^{93}$

The hadith continues with the prediction that the defeat of the Romans gathered for the alMalhamah al-Kubrā will usher in the appearance of the Dajjāl and the sending of a party of ten men to scout the situation:

They [the Muslims] will be in this very state when they will hear of a calamity more horrible than this. And a cry will reach them: The Dajjal has taken your place among your offspring. They will, therefore, throw away the spoils in their hands and go forward, sending ten horsemen as a scouting party. ${ }^{94}$

One variant of the same tradition locates the great battle before the Last Hour in the valleys or $A m \bar{a} q$ of northern Syria or at the town of Dābiq (located north of modern Aleppo), the staging ground for Arab-Islamic raids into Anatolia during the Umayyad period:

The Last Hour will not come until the Romans land at al-Amaq or Dabiq. An army consisting of the best (soldiers) on earth at that time will come from Medina (to counteract them). When they arrange themselves in ranks, the Romans will say: "Do not stand between us and those [Muslims] who took prisoners from amongst us. Let us fight them." The Muslims will say: "Nay, by Allah, how can we withdraw between you and our brothers." They will then fight. A third (part) of the army will run away, whom Allah will never forgive. A third (part of the army), which will be constituted of excellent martyrs in the eye of Allah, will be killed, and the third who will never be put to trial [tempted] will win and they will [go on to] be conquerors in Constantinople. ${ }^{95}$

After the Muslim forces have defeated the Romans gathered for the great apocalyptic battle in the $A m \bar{a} q$ or the town of Dābiq, and in this version of the tradition, gone on to conquer

denoted the Christian peoples of the (eastern) Roman Empire, more commonly referred to as Byzantium. See Cook, Studies in Muslim Apocalyptic, 9; Nadia El-Cheikh and C. E. Bosworth, "Rūm", in Encyclopaedia of Islam Two, ed. P. Bearman, Th. Bianquis, C. E. Bosworth, E. van Donzel, and W. P. Heinrichs, DOI:10.1163/15733912_islam_COM_0939. See also Durak, Koray. "Who Are the Romans? The Definition of Bilād al-Rüm (Land of the Romans) in Medieval Islamic Geographies", Journal of Intercultural Studies 31 (2010): 285-98.

93 Sahīh Muslim, Book 54, Chapter 11.

94 Șahịh Muslim, Book 54, Chapter 11.

95 Șạihh Muslim, Book 54, Chapter 9. 
Constantinople, the Antichrist, who "will be followed by seventy thousand Jews of Isfahan wearing Persian shawls", ${ }^{96}$ will then intervene on behalf of its Christian followers. The hadìth continues:

When they [the Muslims] have hung their swords on the olive trees and divided up the spoils, Satan will falsely spread this word amongst them: "The Dajjal has taken your place among your family". They will then hasten to leave and, once arrived in Syria, the Antichrist will come out. The Muslim soldiers will then prepare to do battle with him and draw up their ranks. ${ }^{97}$

The scene is now set for a great messianic confrontation. The Qur'an calls Jesus Christ "the Messiah, Isa, son of Mariam". ${ }^{98} \mathrm{He}$ was the eleventh of the twelve messengers of Allah, and he acquired a central place in the Islamic apocalyptic traditions.

The time of prayer shall come and then Jesus (peace be upon him) son of Mary will descend [from heaven] and will lead them [Muslim soldiers]. When the enemy of Allah [the Antichrist] will see him [Jesus], it [the Antichrist] will (disappear) just as salt dissolves itself in water, and if he (Jesus) were not to confront them [the Antichrist and his army of evil followers] at all, even then it [the Antichrist] would dissolve completely, but Allah will kill them [the Antichrist and his army of evil followers] by his [Jesus's] hand and he [Jesus] would show them their blood on his lance. ${ }^{99}$

Elsewhere an authentic tradition records that with the appearance of the Dajjāl,

Wreaking havoc right and left $\cdots$ Allah will send the Messiah, Jesus, son of Mary, and he will descend at the white minaret in the eastern side of Damascus wearing two garments lightly dyed with saffron and placing his hands on the wings of two Angels. When he lowers his head, beads of perspiration will fall from it, and when he raises, beads like pearls will scatter from it. Every infidel who smells the breath [of Jesus] will die and his breath will reach as far as he will be able to see. He will then search for him (Dajjal) until he catches hold of him at the gate of Ludd [Lod, modern Israel] and then he [Jesus] will kill him. ${ }^{100}$

After his descent from heaven to fight alongside Muslims in his messianic battle with the Antichrist and his demonic Jewish and Christian supporters, and following his subsequent execution of the Dajjāl, Jesus will, eventually, usher in a millenarian age of peace, justice, prosperity and the universal reign of Islam for, as the Messenger of Allah said:

\footnotetext{
${ }^{96}$ Șahīh Muslim, Book 54, Chapter 25.

97 Sahịh Muslim, Book 54, Chapter 9.

${ }^{98}$ The Qu'ran, 4: 171. trans. M. A. S. Abdel Haleem, rev. ed. (Oxford, 2016), 66. Haleem's translation renders 'Issa' as 'Jesus' and 'Mariam' as 'Mary'.

99 Șậhh Muslim, Book 54, Chapter 9.

100 Șahịh Muslim, Book 54, Chapter 20.
} 
By Him in Whose hand is my life, the son of Mary will soon descend among you as a just judge. He will break crosses, kill swine and abolish Jizya and the wealth will pour forth to such an extent that no one will accept it [as charity]. ${ }^{101}$

101 Șaḥịh Muslim, Book 1, Chapter 71. 